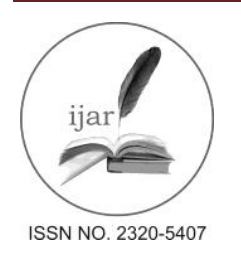

\section{Journal home page: http://www.journalijar.com Journal DOI:10.21474/IJAR01}

\section{RESEARCH ARTICLE}

INTERNATIONAL JOURNAL

OF ADVANCED RESEARCH

\title{
EFFECT OF CHAMAEMELUM NOBILE AND CHRYSANTHEMUM SEGETUM EXTRACTS ON RUMINAL METHANOGENESIS, IN VITRO DEGRADABILITY AND METHANE FORMING POPULATION
}

\author{
Serine Amokrane ${ }^{1}$, Rabah Arhab $^{2}$, Raffaella Tudisco ${ }^{3}$, Hamza Rahab ${ }^{1}$, Federico Infascelli ${ }^{3}$ Serina Calabro ${ }^{3}$. \\ 1. Biotechnology Research Center (C.R.Bt),Ali Mendjli, Nouvelle Ville, UV 03 BP E73 Constantine, Algeria \\ 2. Departement des sciences de la nature et de la vie, Faculté des Sciences Exactes et des Sciences de la Nature et \\ de la Vie, Université Larbi Ben Mhidi, Oum El Bouaghi, Algerie. \\ 3. Department of Veterinary Medicine and Animal Production (DMVPA), University of Napoli Federico II, Via F \\ Delpino 1, 80137 Napoli, Italy.
}

\section{Manuscript Info}

Manuscript History:

Received: 18 March 2016

Final Accepted: 22 April 2016

Published Online: May 2016

Key words:

Methanogenesis, Chamaemelum nobile, Chrysanthemum segetum, extracts, flavonoids, Methanogens

\section{*Corresponding Author}

Serine Amokrane.

\begin{abstract}
The objective of this study was to evaluate the effects of two plants rich in phenolics compounds on ruminal fermentation, methane production and related microbial diversity using in vitro gas production technique (IVGPT). $25 \mathrm{mg}$ of the two plant extracts added to $1.0 \mathrm{~g}$ of mixture of alfalfa hay, ryegrass hay and corn $(5,2,3)$ were incubated with $30 \mathrm{ml}$ of buffered rumen fluid (1:2) in $120 \mathrm{ml}$ serum bottles. After 24h, the incubation was stooped and the inoculants were determined for $\mathrm{pH}$, ammonia-N, VFA, truly organic matter digestibility, methanogens and protozoa quantification using real time PCR technique. In vitro gas production was recorded and methane concentration was determined at 3,6, 9, 12 and 24h of incubation. Results showed that methane and ammonia nitrogen production was significantly reduced $(\mathrm{p}<0.05)$, propionate production was increased significantly $(\mathrm{p}<$ 0.05 ), while no significant effect was registred for $\mathrm{pH}$, tVFA and organic matter digestibility comparatively to the control. Real time PCR indicated that the ciliate protozoa population in the two added extracts was decreased $(p<0.05)$, while no effect was observed on methanogens population. Among phenolics fractions, total flavonoids had the closest relationship with $\mathrm{CH}_{4}$ production $(\mathrm{r}=-0.916, \mathrm{p}<0.01)$ followed by total phenols $(\mathrm{r}=-0.861, \mathrm{p}<$ $0.01)$ and condensed tanins $(r=-0.538, p<0.05)$. In conclusion, the plants rich in flavonoids might be promising to be used as a potent antimethanogenic additive for decreasing $\mathrm{CH}_{4}$ while they obviously enhance microbial biomass production and fermentation effeciency.
\end{abstract}

Copy Right, IJAR, 2016. All rights reserved.

\section{Introduction}

The largest source of agricultural greenhouse gas (GHG) emissions is methane produced from enteric fermentation as an end product of a complex anaerobic degradation pathway of plant biomass. The fermentation process is carried out by a specific group of microbes known as Archaea called methanogens wich is presented as free-living methanogens (FLM), or protozoa-associated methanogens (PAM) (Stumm et al., 1982; Carberry et al., 2014 ; Belanche et al., 2014).Emissions from enteric fermentation increased 11 percent from $1.858 \mathrm{Mt} \mathrm{CO} 2 \mathrm{eq}$ to $2.071 \mathrm{Mt}$ CO2 eq between 2001 and 2011(Tubiello et al., 2014).In respect of this average, and global demands for milk and meat expected to double by 2050, global agricultural emissions are expected to increase in 2030 and 2050 by $18 \%$ and $30 \%$, respectively (Tubiello et al., 2014). Moreover, methanogenesis process represents a significant loss in energy (2-15\%) from dietary gross energy intake; hence, reducing methanogenesis is of both environmental and economic benefits (Van Nevel and Demeyer, 1996). Since this time, animal nutritionists have tried to reduce $\mathrm{CH}_{4}$ losses from the rumen testing several technologies that range from feeding management to animal breeding, 
immunization and genetic transformation of rumen microorganisms (Lascano and Cárdenas, 2010). Nowadays, plant extracts containing high levels of secondary metabolites (saponins, tanins, flavonoids, essential oils), as potential substitutes for chemical feed additives, are an important contemporary research topic in methane mitigation strategies, since several have shown antimicrobial activity, as they can modify ruminal fermentation in a way that the efficiency of utilization of feed energy is enhanced and methane production is decreased (Bodas et al., 2009; Patra and Saxena, 2010).

The Asteraceae family is one of the largest families of flowering plants, consisting of approximately 1.600 genera and over 23,000 species. Despite the global distribution of Asteraceae plants and their potential use as sources of antimicrobial agents, the bioactive properties of several species are not yet investigated (Kenny et al., 2014).The plants Chamaemelum nobile and Chrysanthemum segetum have been chosen mainly, for their wide variety of medicinal properties (i.e. antibacterial, anti-inflammatory, and others multiples medicine applications), and for their abundance in wild and cultivated habitats in eastern of Algeria. The objective of the present study was to test the antimethanogenic effect of the two extracts in vitro, in particular, the fermentation parameters, methane production, methanogens and protozoa counts were studied. We sought firstly to investigate extract (s) that have a hight $\mathrm{CH}_{4}$ mitigating potential. Secondly, we aimed to elucidate relationships among differents phenolic fractions and $\mathrm{CH}_{4}$ production in vitro.

\section{Material and Methods \\ Sample collection and preparation}

Samples of plants were collected during the flowering stage in a wild population in IBN ZIAD, located in Northwest of Constantine, Algeria $\left(36^{\circ} 22^{\prime} 45^{\prime \prime}\right.$ latitude, $6^{\circ} 28^{\prime} 19^{\prime \prime}$ longitude). Selection of the species was based on the breeders declaration on their consumption by grazing small ruminants, in addition to their potential abundance in the area of study. The aerial part of the tested plants (stems, leaves and flowers) were cleaned, air-dried and ground to pass through a 1-mm screen (BRABENDER Wiley mill, BRABENDER OHG Duisburg,Germany), and kept in closed jars in a dry and cool place.

\section{Chemical analysis \\ Proximate analysis}

The two plants were analyzed according to AOAC procedures (AOAC,1990) for dry matter (DM; ID 934.01) by drying samples at $105^{\circ} \mathrm{C}$ overnight, ash (ID 942.05) by ashing the samples in a muffle furnace at $550^{\circ} \mathrm{C}$ for $8 \mathrm{~h}$, and ether extract (EE; ID 920.39) using Soxhlet apparatus, Nitrogen (N) content was determined using Kjeldahl method (ID 954.01) using a Kjeltec Auto System, crude protein content (CP) was calculated as Nx6.25.Neutral detergent fibers (NDF, with sodium sulfite and heat-stable $\alpha$-amylase and expressed exclusive of residual ash), acid detergent fibers (ADF, expressed exclusive of residual ash) and acid detergent lignin (ADL, determined by solubilization of cellulose with sulphuric acid) were analyzed according to Van Soest et al (1991) using ANKOM ${ }^{200}$ Technology, Fairport, New York, NY, USA. Hemicellulose (HC) and cellulose (C) were estimated as the difference between $\mathrm{NDF}$ and ADF and between ADF and ADL respectively. In the same way, proximate analysis of control $(50 \%$ alfalfa hay, $20 \%$ ryegrass hay and $30 \%$ corn) has been done in the same conditions. All measurements were carried out in triplicate and are calculated as average of three analyses \pm standard deviation.

\section{Extraction procedure}

Air-dried and powdered aerial parts of the tested plants were macerated in an aquous-ethanolic solution $(80: 20 \mathrm{~V} / \mathrm{V}$; $1: 10 \mathrm{~W} / \mathrm{V}$ ) for $24 \mathrm{~h}$ at room temperature. The use of the ethanol as solvent is justified by the hight extraction yield (\%) obtained through several previous studies in our laboratory (results not shown). The extract was filtered through Whatman No. 1, and the residue was submitted to two consecutive extractions in the same conditions; then the extracts were unified, evaporated under reduced pressure in a rotary evaporateur (Rotavapor R.215.BUCHI, Switzerland), then lyophilized (Alpha 1-4 LD plus, BIOBLOCK SCIENTIFIC) and stored at $4^{\circ} \mathrm{C}$ untill use.

\section{Phenolic content determination}

For each extract, total phenolic (TP) content was determined with Folin-Ciocalteu's reagent (FCR) according to Singleton et al (1999). Briefly, $125 \mu \mathrm{l}$ of ethanolic extract solution was mixed with $125 \mu \mathrm{l}$ of FCR and $500 \mu \mathrm{l}$ of distilled water. After $3 \mathrm{~min}, 1.25 \mathrm{ml}$ of $\mathrm{Na}_{2} \mathrm{CO}_{3}$ solution (2\%)was added to the mixture and the reaction was kept in darkness at room temperature for $90 \mathrm{~min}$, the absorbance was then read at $760 \mathrm{~nm}$ using UV-visible spectrophotometer (Cary UV 60, AGILENT, Malaysia). The total phenolic contents were calculated on the basis of 
the calibration curve of gallic acid $(y=0.0042 x+0.0334$, where $x$ and $y$ express gallic acid concentration $(\mu \mathrm{g} / \mathrm{ml})$ and absorbance at $760 \mathrm{~nm}$ respectively; $\mathrm{R}^{2}=0.9998$; $\left.\mathrm{SEy}=0.514\right)$ and expressed as micrograms of gallic acid equivalents.

The aluminium nitrate method was used to determine the total flavonoid (TF) content according to Türkoğlu et al (2007). Ethanolic extract solution $(250 \mu \mathrm{l})$ was mixed with $2.55 \mathrm{ml}$ of ethanol $(96 \%), 0.1 \mathrm{ml}$ of aluminium nitrate and $0.1 \mathrm{ml}$ of aqueous potassium acetate $(1 \mathrm{M})$. After $40 \mathrm{~min}$ at room temperature, the absorbance was measured spectrophotometrically (Cary UV 60, AGILENT, Malaysia) at $415 \mathrm{~nm}$. Total flavonoid concentration was expressed as micrograms of quercetin equivalents $\left(y=0.0016 x+0.0184, R^{2}=0.9893 ; \mathrm{SEy}=0.0129\right)$.

Total saponins (TS) concentration was determined according to the method of Hiai et al (1976). The ethanolic extract of each plant $(50 \mu \mathrm{l})$ were mixed with vanillin $(8 \%)$ and sulfuric acid $(72 \%)$. The mixture was incubated at $60^{\circ} \mathrm{C}$ for $10 \mathrm{~min}$ and cooled for $15 \mathrm{~min}$; the absorbance was then read at $544 \mathrm{~nm}$. Total saponin content was expressed as quillaja saponin equivalents $\left(y=0.0538 x+0.1325, R^{2}=0.9867 ; \mathrm{SEy}=0.0075\right)$.

Condensed tannins (CT) were analysed by the vanillin-HCl method (Heimler et al., 2006).Reaction mixture was prepared by adding $5 \mathrm{ml}$ of the vanillin- $\mathrm{HCl}$ reagent to $1 \mathrm{ml}$ of each ethanolic solution. After a mixing step, the mixtures were incubated for $20 \mathrm{~min}$ in a water bath at $30^{\circ} \mathrm{C}$, and the absorbance was measured at $500 \mathrm{~nm}$ by means of an UV-visible spectrophotometer (Cary UV 60, AGILENT, Malaysia). Condensed tannin content of samples was then expressed in terms of catechin equivalents using the equation obtained from the standard catechin graph $(\mathrm{y}=$ $\left.11.556 \mathrm{x}+0.0137, \mathrm{R}^{2}=0.9823 ; \mathrm{SEy}=1.668\right)$. Measurements are calculated as average of three analyses \pm standard deviation.

\section{Ruminal sampling and in vitro incubation}

The antimethanogenic activities of the ethanolic extracts of C.nobile and C.segetum were assessed using the in vitro gas production technique (IVGPT) in $120 \mathrm{ml}$ serum bottles. Three male cows (mean weight $\pm 680 \mathrm{~kg}$ ) received daily, in two equal portions, standard diet composed of $50 \%$ grass hay and $50 \%$ of concentrate mixture formulated, were used as rumen fluid donors. Equal volume was collected from each cow just before the morning feeding, the collected inocula were rapidly transported to the laboratory, where it was strained and mixing with buffer medium in the ratio of 1 to 2 as described by Menke and Steingass (1988). $30 \mathrm{ml}$ of the incubation medium was dispensed anaerobically into each serum bottle containing approximately $(1.0063 \mathrm{~g} \pm 0.0025)$ of substrate and $25 \mathrm{mg}$ of each plant extract (concentration of $2.5 \%(\mathrm{w} / \mathrm{w})$ of the substrate on dry matter basis).Concentration of extract used in the present study was based on the result of a preliminary in vitro study in our laboratory with three doses $(0,2.5$ and $5 \%$ ). The serum bottles were sealed and held in an orbital incubator (STUART, S1500, UK) at $39 \pm 0.5^{\circ} \mathrm{C}$ for 24. Three replicates for each extract were made, and three bottles without extracts were incubated to correct gas, methane and volatile fatty acids (VFA) productions.

\section{Fermentation parameters}

Immediately after $24 \mathrm{~h}$ of incubation, total volume of gas (related to incubated organic matter, $\mathrm{ml} / \mathrm{g}$ ) accumulated in the headspace of each bottle was recorded following the reading pressure technique as described by Theodorou et al (1994) by using a manual pressure transducer (COLE AND PARMER Instrument Co, Illinois, USA). For methane measurement, $1 \mathrm{ml}$ of the gas phase from each of the bottles was sampled with a gastight syringe for $\mathrm{CH}_{4}$ analysis using a gas chromatograph (GC-17 A, SHIMADZU, Japan) equipped with Porapack Q column 80/100,TCD (Thermal Conductivity Detector) and FID (Flame Ionization Detector). Methane production readings were recorded at incubation times of $3,6,9,12$, and $24 \mathrm{~h}$, then, the $\mathrm{pH}$ of the media culture was measured (HANNA instruments.Inc.woonsocket.RT.USA). Samples of the acidified liquid contents $(1 \mathrm{ml}$ of supernatant mixed with $1 \mathrm{ml}$ of oxalic acid $0.06 \mathrm{~mol}$ ) were centrifuged $\left(10 \mathrm{~min}\right.$ at $12,000 \mathrm{~g}$ at $\left.4 \mathrm{C}^{\circ}\right)$, and the supernatant was used for VFA analysis by gas chromatography equipped with packed $15 \%$ SP-1220/1\% $\mathrm{H}_{3} \mathrm{PO}_{4}$ on $100 / 120$ column. The ammonia nitrogen content was determined by the Kjeldahl procedure (AOAC, 1990).The truly organic matter digestibility (IVOMD \%) was determined by weight difference of the incubated OM and the undegraded residue (sintered glass crucibles; SCHOTT DURAN, Mainz, Germany, porosity \# 2).

\section{Methanogenic Archaea and Ciliate Protozoa quantification}

Rumen DNA extraction: Total rumen microbial DNA was immediately isolated from fermentation liquor using the FastDNA Spin Kit for soil (MP BIOMEDICALS, Heidelberg, Germany) according to manufacturer's guidelines. For each sample, $1.5 \mathrm{ml}$ aliquot taken from each serum bottles were centrifuged at $12,000 \mathrm{~g}$ for $5 \mathrm{~min}$ and the 
supernatant was removed before DNA extraction. Total genomics DNA isolated in duplicate was purified using the silica-based $\operatorname{spin}^{\mathrm{TM}}$ filter method, and stored at $-20^{\circ} \mathrm{C}$ until the analysis. Nucleic acid concentrations were measured by spectrophotometer (NANODROP 2000c, THERMO SCIENTIFIC, German) and evaluated by separating $2 \mu$ of each sample on agarose gel in 1x Tris-Borate-EDTA buffer $0.8 \%(\mathrm{w} / \mathrm{v})$.

Primers and quantitative Real-time PCR: The primer sets for total bacteria were the following: 5'GTGSTGCAYGGYTGTCGTCA-3' and R: 5'-ACGTCRTCCMCACCTTCCTC-3' (Maeda et al., 2003). The primer sets for quantification of methanogenic Archaea were targeted against the methyl coenzyme-M reductase (mcrA) gene : forward: 5'-TTCGGTGGATCDCARAGRGC-3' was designed to target the conserved amino acid sequence FGGSQR, while the reverse primer 5'-GBARGTCGWAWCCGTAGAATCC-3' targeted the GFYGYDL conserved amino acid sequence (Denman et al., 2007). Assays were set up using the SYBR ${ }^{\circledR}$ Green PCR Master Mix (APPLIED BIOSYSTEMS), $300 \mathrm{nM}$ forward and reverse primers, DNA template (100 ng) and water to $25 \mu 1$, under the following conditions: one cycle of $50^{\circ} \mathrm{C}$ for $2 \mathrm{~min}$ and $95{ }^{\circ} \mathrm{C}$ for $2 \mathrm{~min}$ for initial denaturation, $40 \mathrm{cycles}$ at $95^{\circ} \mathrm{C}$ for $15 \mathrm{~s}$ and $60^{\circ} \mathrm{C}$ for $1 \mathrm{~min}$ for primer annealing and product elongation.For ciliate Protozoa enumeration, the primers were targeted against 18S rDNA gene: F: 5'-GAGCTAATACATGCTAAGGC-3' and R: 5'CCCTCACTACAATCGAGATTTAAGG-3' (Skillman et al., 2006). $1.2 \mu$ of DNA template was used in $30 \mu 1$, which included $15 \mu$ of SYBR ${ }^{\circledR}$ Green PCR Master Mix (APPLIED BIOSYSTEMS), ) and $400 \mathrm{nM}$ of each primer. Cycling conditions were: $50^{\circ} \mathrm{C}$ for $2 \mathrm{~min}$ and $95^{\circ} \mathrm{C}$ for $8 \mathrm{~min}$, followed by 40 cycles of $95^{\circ} \mathrm{C}$ for $15 \mathrm{~s}, 55^{\circ} \mathrm{C}$ for $30 \mathrm{~s}$, and $72^{\circ} \mathrm{C}$ for $30 \mathrm{~s}$, with a final step of $72^{\circ} \mathrm{C}$ for $5 \mathrm{~min}$ (Hook et al., 2011). The qPCR assays were performed on a 7300 Real-Time PCR System (APPLIED BIOSYSTEMS). Each qPCR was done in triplicate. SDS software (APPLIED BIOSYSTEMS) was utilized to enumerate the mean methanogens and ciliate protozoa and multiplied by the dilution factor to determine the total number of them. A negative control without the template DNA was used in every qPCR assay. The relative quantification of methanogenic Archaea and ciliate Protozoa were expressed as a proportion of total rumen bacterial 16S rDNA according to the equation of Denman and McSweeney, (2005):

Relative quantification $=2^{-(\mathrm{Ct} \text { target-Ct total bacteria) }}$

Where $\mathrm{Ct}$ represents threshold cycle.

\section{Calculations and statistical analysis}

The partitioning factor (PF), as an indicator of fermentation effeciency, is calculated as the ratio of substrate (truly degraded dry matter) in vitro $(\mathrm{mg})$ to the volume of gas $(\mathrm{ml})$ produced by it.

The Microbial Biomass yield (MBM) was calculated by using the degradability of substrate and gas volume and stoichiometrical factor (Blûmel et al., 1997):

MBM $(\mathbf{m g})=$ substrate truly degraded $-($ Gas volume $\times$ stoichiometrical factor $)$;

Where, the stoichiometrical factor $=2.25$.

Relative (R) effect provides an indication of the comparative separation between test and control means $(\mu)$ :

$\mathbf{R}=\mu$ test $/ \mu$ control

If $\mathbf{R}$ equals unity $(\mathrm{R}=1)$, test value is identical to control, lower values $(\mathrm{R}<1)$ indicate a decreasing production in the test treatment comparatively to the control, however, higher values $(\mathrm{R}>1)$ indicate that methane has been increased in response to the plant additive (López et al., 2010)

- Relative R' (percentage) increase (positive) or decrease (negative) in methane production provides the percentage of change (increase or decrease) observed in the test bottles compared with the control values (López et al., 2010):

$\mathbf{R}^{\prime}=(\mu$ test $-\mu$ control $) / \mu$ control

The data from the experiments were analyzed using one way ANOVA in Statistical Package for the Social Sciences (IBM SPSS Statistics, version 17.0.0.3, 2009) using the model:

$Y_{i j k}=\mu+S_{i}+\varepsilon i_{j k}$, where:

$\mathrm{Y}:$ is the single observation;

$\mu$ : the general mean;

$\mathrm{S}:$ the extract effect (C. nobile extract or $C$. segetum extract).

$\varepsilon$ : the error. 
The minimum significant difference was generated from tukey's test as the basis of the multiple comparisons among means. The magnitude of correlation between variables was done using Pearson's multiple comparisons tests.

\section{Results and discussion}

Chemical composition and phytochemicals content

The proximate analysis of the two species and diet control are reported in table $\mathbf{1 .}$

Table 1. Chemical composition ( $\left.\mathrm{g} \mathrm{kg}^{-1} \mathrm{DM}\right)$, and phytochemicals content $\left(\mathrm{g} \mathrm{kg}^{-1} \mathrm{DM}\right)$ of the two tested plants and control diet (Means \pm SD).

\begin{tabular}{|c|c|c|c|}
\hline Components & Diet control & Chamaemelum nobile & Chrysanthemum segetum \\
\hline DM & $908.2 \pm 0.57$ & $939.1 \pm 5.23$ & $932.2 \pm 0.71$ \\
\hline Ash & $60.9 \pm 0.28$ & $139.4 \pm 3.82$ & $108.4 \pm 2.55$ \\
\hline CP & $90.5 \pm 0.14$ & $94.8 \pm 0.21$ & $50.5 \pm 3.54$ \\
\hline EE & $17.9 \pm 0.22$ & $84.1 \pm 1.70$ & $49.35 \pm 0.92$ \\
\hline NDF & $426.3 \pm 0.71$ & $399.05 \pm 5.59$ & $470 \pm 5.09$ \\
\hline ADF & $329.9 \pm 0.35$ & $319.3 \pm 7.28$ & $422.75 \pm 0.64$ \\
\hline ADL & $61.6 \pm 0.21$ & $80.05 \pm 1.20$ & $373.75 \pm 2.09$ \\
\hline Cellulose (C) & $267.4 \pm 0.71$ & $239.2 \pm 6.08$ & $47.25 \pm 5.73$ \\
\hline Hemicelluloses (HC) & $97.5 \pm 0.49$ & $79.8 \pm 12.87$ & $321.75 \pm 10.25$ \\
\hline NFC & $404.4 \pm 0.57$ & $282.6 \pm 3.68$ & $207.3 \pm 6.83$ \\
\hline TP & N.D & $99.4 \pm 1.85$ & $58.9 \pm 1.40$ \\
\hline TF & N.D & $46.1 \pm 3.97$ & $0.48 \pm 0.03$ \\
\hline TS & N.D & $1.3 \pm 0.04$ & $47.5 \pm 0.005$ \\
\hline CT & N.D & $0.81 \pm 0.001$ & . \\
\hline
\end{tabular}

DM : Dry matter ; CP : Crude protein ; EE : Ether extract ; NDF : Neutral detergent fiber ;ADF : Acid detergent fiber ; ADL : Acid detergent lignin ; NFC : Non Fibrous Carbohydrates: $100-(\% \mathrm{NDF}+\% \mathrm{CP}+\% \mathrm{EE}+\% \mathrm{Ash})$; NRC (2001) ;TP : Total Phenol ; TF : Total Flavonoids ;TS : Total Saponins ; CT: Condensed tanins ; ND : non determined.

Chemical composition of the two plants was relatively equivalent except for protein and oil content. The main constituents in the tested plants were structural carbohydrates (between $40 \%$ and $47 \%$ DM) followed by non-fibrous carbohydrates (ranged from $28.2 \%$ to $32.1 \% \mathrm{DM}$ ), and ashes (between 10.8 and $13.9 \%$ DM). According to Guimaràtes et al (2013), carbohydrates are the most abundant macronutrients followed by proteins in C.nobile, the fructose is the most abundant sugar, followed by glucose and sucrose. The Crude Protein (CP) content varied relatively between the species samples, being particularly high in C.nobile ( $94.8 \mathrm{~g} / \mathrm{kg} \mathrm{DM})$ comparatively to $C$. segentum $(50.5 \mathrm{~g} / \mathrm{kg} \mathrm{DM})$.It is reported by Hariadi and Santoso (2010) that crude protein concentrations below the threshold of $70 \mathrm{~g} \mathrm{~kg}^{-1}$ DM limit microbial activity due to a lack of nitrogen. However, CP levels above this threshold, as registred for C.nobile, are considered to enhance microbial development in the rumen, which could give C.nobile a wide nutritional benefit to supplement azote poor quality feedstuffs. Regarding lipid content, $C$. segentum showed half oil content $(4.9 \% \mathrm{DM})$ compared to C.nobile $(8.41 \% \mathrm{DM})$. Furthermore, the analysis of insoluble dietary fibers (cellulose, hemicelluloses and lignin) contents showed that celluloses were the most abundant fraction (37.3\% and 23.9\% DM for C. segentum and C.nobile, respectively).Whereas, lignin was the less abundant fraction, being two times superior for C.nobile $(8 \% \mathrm{DM})$ comparatively to that recorded for $C$. segentum $(3.6 \% \mathrm{DM})$.

Our results were not far from those reported for similar species (Guimaràtes et al., 2013 ; Kulivand and Kafilzadeh, 2015) and for other Asteraceae species (Cabiddu et al., 2000;Boufennara et al., 2012; Moujahed, 2013 ; Ayeb et al., 2013), as well as from others Mediterranean's shrubs (Ammar, 2005; Arhab et al., 2009). The differences observed between authors were probably due to the discordance between geographical location, season, and maturity stage of plants while sampling.

Quantitative phytochemicals analysis showed that our samples contained antinutritive factors such as flavonoids and tannins. There was a wide variation in TP content. C.segetum presented two fold higher content of phenolics (207.3 $\mathrm{g} / \mathrm{kg}$ DM) comparatively to C.nobile $(99.4 \mathrm{~g} / \mathrm{kg} \mathrm{DM})$. The highest level of TF value was noted for C. segetum 
(58.9g/kg DM) as compared to C.nobile $(46.1 \mathrm{~g} / \mathrm{kg} \mathrm{DM})$. C.nobile was distinguished by significantly lower levels of saponins and tanins (1.3 and $0.81 \mathrm{~g} / \mathrm{kg} \mathrm{DM}$, respectively) which would be of little significance in its effects on digestion of nutrients by ruminants. As flavonoids represented almost $50 \%$ of the polyphenolic compound, these constituents can be considered the major phenolic compounds in C.nobile. However, TF and TT represent 51\% of the total phenols fraction in C.segetum (28.5 and 23\% respectively). The presence of other phenolic compounds such as tannins in C. segetum $(47.5 \mathrm{~g} / \mathrm{kg}$ DM) comparatively to C.nobile $(0.81 \mathrm{~g} / \mathrm{kg} \mathrm{DM})$ may help explain differences regarding effect of the two plants extracts on digestibility and methanogenesis.For comparative purpose, Fraisse et al (2011) have studied 18 Asteraceae species for their total phenols and flavonoids contents, all taxa found to contain high quantities of total polyphenolic compounds (from $25 \mathrm{~g} / \mathrm{kg}$ to more than $80 \mathrm{~g} / \mathrm{kg}$ ), however flavonoids concentrations ranged from $1.62 \mathrm{~g} / \mathrm{kg}$ to $23.44 \mathrm{~g} / \mathrm{kg}$. C.nobile investigated in our study showed 2 fold higher content of total flavonoids than value $22.33 \mathrm{~g} / \mathrm{kg}$ DM as reported by the same authors, whereas, total phenolics contents is lower than value obtained in our trial (64.08 against $99.4 \mathrm{~g} / \mathrm{kg}$ DM respectively). Likewise, Boufennara et al (2012) have reported, by studying 9 species belonging to 4 differents families, that The highest contents of total phenolics and tanins were observed in the Asteraceae family (Artemisia spp.) as compared to the others families. The tanins content of C.segetum extract was similar to that reported by Arhab et al (2009) for palms leaves ( $49.1 \mathrm{~g} / \mathrm{kg} \mathrm{DM})$ as well as Persea americana (46 g/kg DM) and Hibiscus tiliaceus (42 g/ $\mathrm{kg} \mathrm{DM})$ belonging to Laureaceae and Malvaceae families, respectively as reported by Jayanegara et al (2011).Discordances in phytochemicals analysis observed between studies could be due to differences in location of samples and plant maturity. According to their UV and mass spectra characteristics, Guimarães et al (2013) have reported that the main phenolic compounds found in C. nobile are flavonoids (flavonols and flavones), phenolic acids and derivatives. $340 \mathrm{~g}$ of polyphenolic compounds including $236 \mathrm{mg} / \mathrm{l}$ of flavonoids are quantified in C.nobile flowers infusion where the most part of flavonoids has been corresponded to apigenin derivatives (Carnat et al., 2004; Srivastava and Gupta, 2009). Öksüz and Wagner (1982) have reported that Chrysanthemum species contain mainly sesquiterpenes lactones, flavonoids and coumarins. Geissman and Steelink (1957) reported the presence of quercetin 7-O-glucoside and gossypetin 7O-glucoside in petals of Chrysanthemum segetum. However, in the same part, Stich et al (1996) reported the presence of gossypetin flavonoids as the main components particularly responsible for the yellow colouration of the petals. In addition, Williams et al (2001) have confirmed the presence of luteolin 7-glucoside as vacuolar constituent in $C$. segetum.

\section{Ruminal fermentation parameters}

In this paper, the in vitro gas production technique (IVGPT) has been used, as an approuved method, to test the efficacy of two plant extracts in decreasing methane production in vitro. thus, we examined the extracts of two polyphenol-containing plants (Chrysanthemum segetum and Chamaemelum nobile) belonging to the Asteraceae family since there are no/little reports in literature regarding the use of these extracts and theirs phytochemicals contents as additives to modify methanogenesis and rumen fermentation pattern.

Total gas production and $\mathrm{pH}$ were not significantly influenced by the addition of the two plant extracts (Table 02). However, OM digestibility (IVOMD) in added C.nobile extract was highest $(45.15 \%)$ while that of C. segetum extract was lowest (43.9\%) compared to the control (44.4\%). This slight difference among the two species extracts in digestibility may be partly attributed to the variations in chemical composition (mainly cell wall and fermentescibles sugar contents) (table 01). For C.segetum, the lowest IVOMD could be explain by the fact that tannins containing in the extract has the ability to bind protein by forming hydrogens bonds between the phenolic sub-units of the polymer and the carbonyl groups of peptides of the protein, thus forming precipitates which will overestimate the undegradable fraction as suggested by several authors (Makkar et al., 1995a; McSweeney et al., 2001 ; Tiemann et al., 2008). The range of $\mathrm{pH}$ (7.07-7.08) is optimum for methane emission (7.0-7.2), gas production (6.6-7.6) (Kumar et al., 2009) and all rumen microbes development, especially for methanogens growing (6.0-8.0) (Stewart and Bryan, 1988).Our result supports several previous studies where $\mathrm{pH}$ and total gas production were not significantly different with the addition of some plants extract in in vitro ruminal incubation (Kim et al., 2012; Santoso et al., 2013; Kim et al., 2015). Efficiency of microbial protein production in vitro, estimated by the partionning factor (PF) at $24 \mathrm{~h}$, was significantly improved with CNE by $10.77 \%$, whereas CSE had a similar fermentation effeciency as the control (4.93 and 4.89 respectively).The theoretical range for PF values as suggested by Blümmel et al (1997) for tannins free plants is between 2.75 and 4.41. PF values of plants extracts tested in the present study were higher than the theoretical maximum value. According to the same authors, plants with high PF are generally highly digestible. Thus, these results could suggest that our tested plant extracts had a potential nutritive value which tends to enhance microbial synthesis. 
Table 02: Effect of the two plants extracts on total gas, $\mathrm{CH}_{4}$ emission, IVOMD, ammonia, microbial biomass yield and fermentation effeciency parameter after $24 \mathrm{~h}$ in vitro incubation (Means \pm SD).

\begin{tabular}{|c|c|c|c|c|c|}
\hline & Control Diet & CNE & CSE & P-value & S.E.M \\
\hline $\mathrm{pH}$ & $7.08^{\mathrm{a}} \pm 0.04$ & $7.08^{\mathrm{a}} \pm 0.03$ & $7.07^{\mathrm{a}} \pm 0.03$ & 0.795 & 0.007 \\
\hline IVOMD & $44.36^{\mathrm{ab}} \pm 0.80$ & $45.15^{\mathrm{b}} \pm 0.57$ & $43.86^{\mathrm{a}} \pm 0.58$ & 0,014 & 0.194 \\
\hline OMCV, mmol/g IOM & $5.17^{\mathrm{a} \pm 0.08}$ & $5.17^{\mathrm{a}} \pm 0.11$ & $5.07^{\mathrm{a}} \pm 0.42$ & 0,085 & 0.770 \\
\hline $\mathrm{CH} 4, \mathrm{ml} / \mathrm{g}$ IOM & $41.40^{\mathrm{c}} \pm 2.30$ & $25.15^{\mathrm{b}} \pm 1.98$ & $20.61^{\mathrm{a}} \pm 2.81$ & $<0.0001$ & 2.227 \\
\hline $\mathrm{CH} 4, \mathrm{mmol} / \mathrm{g} \mathrm{IOM}$ & $1.85^{\mathrm{c}} \pm 0.10$ & $1.12^{\mathrm{b}} \pm 0.86$ & $0.92^{\mathrm{a}} \pm 0.12$ & $<0.0001$ & 0.099 \\
\hline $\mathrm{CH} 4, \mathrm{mmol} / \mathrm{mmol}$ gas & $35.71^{\mathrm{b}} \pm 2.40$ & $21.72^{\mathrm{a}} \pm 2.05$ & $18.18^{\mathrm{a}} \pm 2.79$ & $<0.0001$ & 1.913 \\
\hline $\mathrm{NH} 3-\mathrm{N}(\mathrm{mg} / \mathrm{l})$ & $14.64^{\mathrm{c}} \pm 0.40$ & $12.88^{\mathrm{b}} \pm 0.34$ & $10.59^{\mathrm{a}} \pm 0.67$ & $<0.0001$ & 0.427 \\
\hline $\mathrm{R}$ & - & $0.61 \pm 0.64$ & $0.48 \pm 0.70$ & - & - \\
\hline $\mathrm{R}^{\prime} \%$ & - & $-39.10 \pm 6.33$ & $-50.20 \pm 6.91$ & - & - \\
\hline $\mathrm{PF}$ & $4.89^{\mathrm{a}} \pm 0.13$ & $5.48^{\mathrm{b}} \pm 0.12$ & $4.93^{\mathrm{a}} \pm 0.11$ & 0.002 & 0.101 \\
\hline MBM, mg & $244.48^{\mathrm{a}} \pm 6.94$ & $271.64^{\mathrm{b}} \pm 8.04$ & $251.87^{\mathrm{a}} \pm 9.00$ & 0.015 & 4.670 \\
\hline
\end{tabular}

IVOMD: The truly organic matter digestibility; OMCV: cumulative gas production related to incubated organic matter; $\mathbf{C H}_{\mathbf{4}}$ : methane related to incubated OM; MBM: Microbial Biomass yield; PF: Partionning Factor; CNE: C.nobile extract; CSE: C. segetum extract; P: Probability; S.E.M., standard errors of means; ${ }^{\text {a, b, c }}$, means with different superscripts within a same line are significantly different $(\mathrm{P}<0.05)$.

The obtained relative effect, lower than unity $(\mathrm{R}<1)$, indicating a decreasing production in $\mathrm{CH}_{4}$ production in the test treatments (López et al., 2010). C. segetum extract has shown an effect more consistent ( $\mathrm{R}=0.61)$ compared to that of C.nobile ( $\mathrm{R}=0.48)$. Methane concentration was decreased at all times of incubation compared to the control (Fig. 1). At $24 \mathrm{~h}$ incubation, addition of $25 \mathrm{mg}$ of CSE and CNE reduced methane concentration by $-50 \%$ and $-39 \%$ respectively (Table 2). These results are inconsistent with those obtained by Garcia-Gonzalez et al (2008a) observed any noticeable effect of Chamaemelum nobile flowers on in vitro methane production and others fermentation parameters. The same tendency is registred for $\mathrm{NH}_{3}-\mathrm{N}$ concentrations, where there was a significant decrease by $12 \%$ and $27 \%$ for C.nobile and C. segetum extracts respectively compared to the control.

The total VFA concentrations were not affected significantly as compared to control. The ratio of acetate to propionate in added C.nobile and C. segetum extracts was significantly lower $(\mathrm{p}<0.05)$ than that of the control (Table 03). It was reported that methane production in the rumen is closely related to the A: $\mathrm{P}$ ratio and the decreased methane emission led to a higher molar proportion of propionate and low A: P ratio (Nellot et al., 1997; Mitsumori et al., 2008). As reported by Demeyer and Van Nevel (1975), the inhibition of methane production by plant additives leads to a channelling of hydrogen from methanogenesis to another hydrogen sink which could be represented, in our study, by an increase of propionate production (25 and 30\% for added CNE and CSE respectively compared to the control), in return, the observed decrease in acetate production may be attributed to a high NADH/NAD+ ratio (Miller, 1995) (table 03).

Table 03: Effect of the two plants extracts on volatile fatty acids production and A/P ratio, after $24 \mathrm{~h}$ in vitro incubation (Means \pm SD).

\begin{tabular}{|c|c|c|c|c|c|}
\hline & Control Diet & CNE & CSE & P- value & S.E.M \\
\hline TVFA, mmol/g IOM & $5.04^{\mathrm{a}} \pm 0.05$ & $4.91^{\mathrm{a}} \pm 0.12$ & $4.85^{\mathrm{a}} \pm 0.32$ & 0.284 & 0.048 \\
\hline Acetate, mmol & $3.09^{\mathrm{b}} \pm 0.10$ & $2.68^{\mathrm{a}} \pm 0.26$ & $2.62^{\mathrm{a}} \pm 0.29$ & 0.006 & 0.072 \\
\hline Propionate, mmol & $1.01^{\mathrm{a}} \pm 0.06$ & $1.27^{\mathrm{b}} \pm 0.58$ & $1.32^{\mathrm{b}} \pm 0.26$ & 0.012 & 0.048 \\
\hline Butyrate, mmol & $0.53^{\mathrm{a}} \pm 0.09$ & $0.68^{\mathrm{a}} \pm 0.08$ & $0.65^{\mathrm{a}} \pm 0.12$ & 0.049 & 0.026 \\
\hline A : P ratio & $3.05^{\mathrm{b}} \pm 0.26$ & $2.10^{\mathrm{a}} \pm 0.21$ & $2.06^{\mathrm{a}} \pm 0.51$ & $<0.0001$ & 0.136 \\
\hline
\end{tabular}
superscripts within a same line are significantly different $(\mathrm{P}<0.05)$. 


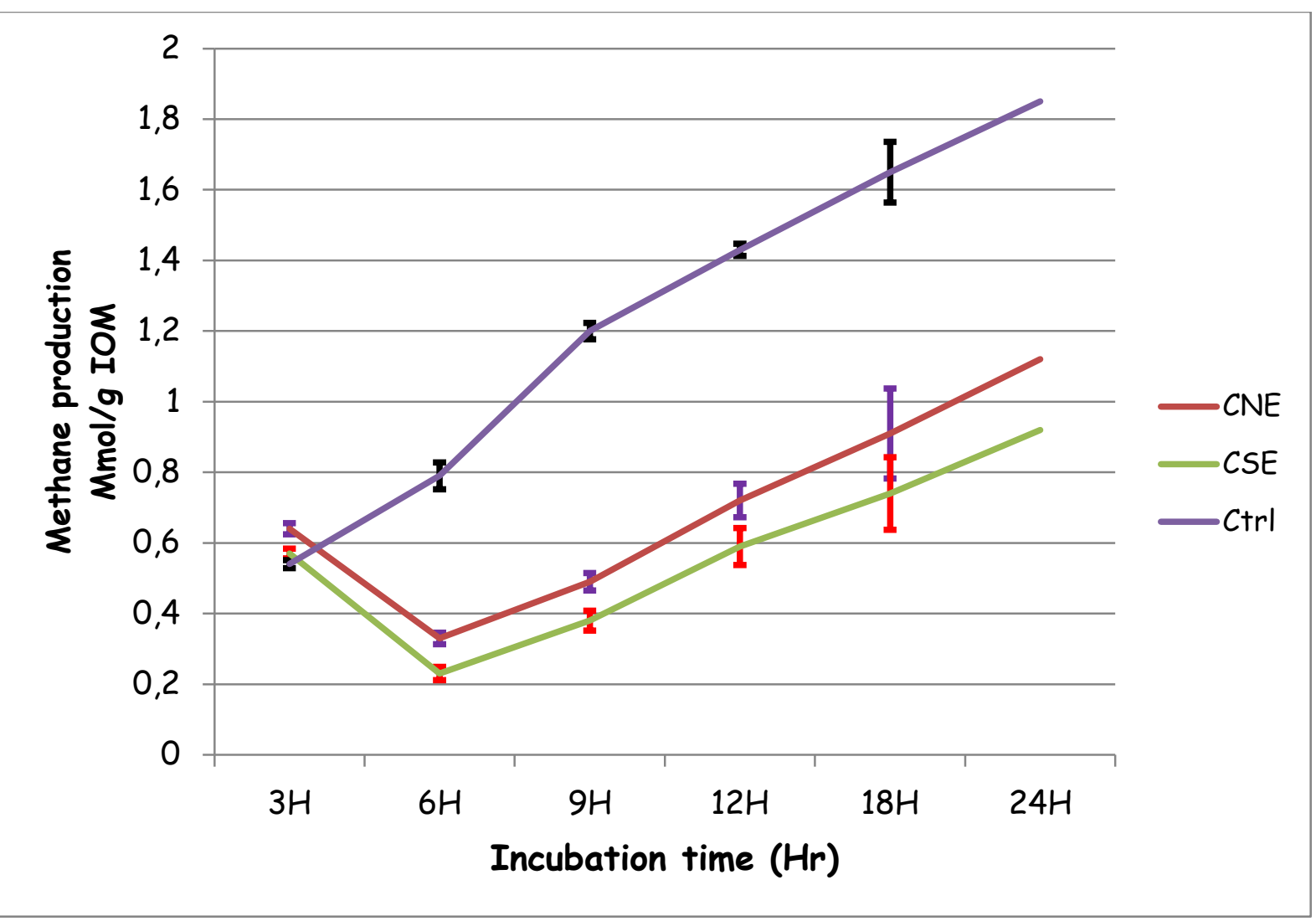

Figure 01: Effect of CSE and CNE addition on methane production after 24h in vitro incubation. Bars indicate standard error.

Extracts of C.nobile and C.segetum were found promising for reducing the proportion of $\mathrm{CH}_{4}$ of total gas formation when incubating them in vitro in a ruminal fluid buffer mixture. Both of them contained substantial amounts of phenolic compounds, although the latter contains 2 fold higher content of phenolics compounds than the former. This supports previous studies which reported that ruminal $\mathrm{CH}_{4}$ production may be lower when using diets containing phenols (Puchala et al., 2005; Animut et al., 2008; Jayanegara et al., 2011). But this is not always the case (Beauchemin et al., 2007; Oliveira et al., 2007), and such discrepancies between studies may be related to the diversity in the structures of phenolic compounds, the activities of the individual phenolic sources, interaction with other compounds and the dosages (Makkar, 2003b; Rochfort et al., 2008).In our study, there was a significant negative correlation between TP, TF and $\mathrm{CT}$ and $\mathrm{CH}_{4}$ production (table 05), indicating that as their concentrations increased, the $\mathrm{CH}_{4}$ production decreased. As TP fraction includes all phenolic fractions which all were found to contribute to the decrease in $\mathrm{CH}_{4}$ production, it is obvious from our study that $\mathrm{TF}$ fraction was more close associated with $\mathrm{CH}_{4}$ reduction $(\mathrm{r}=-0.916, \mathrm{p}<0.01)$ as compared to $\mathrm{CT}$ fraction $(\mathrm{r}=-0.538, \mathrm{p}<0.05)$. Our results strongly suggest that flavonoids contribute the most to reducing $\mathrm{CH}_{4}$ production and it may be particularly useful for a general screening for plants possessing antimethanogenic activity. Otherwise, TF and CT fractions are both associated with a lower $\mathrm{CH}_{4}$ emission, however, the mechanisms through which they decrease $\mathrm{CH}_{4}$ appear to differ.This supports previous studies which reported that ruminal $\mathrm{CH}_{4}$ production may be lower when using diets containing flavonoids (Garcia-Gonzalez et al., 2008a b; Balcells et al., 2012; Oskoueian et al., 2013 ;Seradj et al., 2014). But this is not always the case (Broudiscou et al., 2000, 2002). It has been suggested that potential of flavonoids in reducing $\mathrm{CH}_{4}$ was related to the number and the position of hydroxyl groups and presence of aliphatic and glycosyl groups in their structures., and their antimicrobial activity appears generally through inhibition of cytoplasmic membrane function, inhibition of bacterial cell wall synthesis, or inhibition of nucleic acid synthesis (Cushnie and Lamb, 2011).In addition, interactions with other compounds present in the extracts and their concentrations have been also discussed (Makkar, 2003b;Oskoueian et al, 2013). 


\section{Methane forming population}

The effect of CNE and CSE on the differents ruminal microbes groups were clearly different (table 04) where no effect on methanogens population was observed, while the ciliate protozoal growth was significantly decreased as compared to the control (-23\% and $-45 \%$ for CNE and CSE respectively).These results imply that the supplementation tested did not adversely affect the methanogens population since there were a weak association between either TP, TF or CT and methanogens count (Table 05). We hypothesized that The mixture of flavonoids, tanins and others phenolics compound present in the investigated extracts (as reported previously) likely suppressed methanogenesis indirectly by reducing the protozoal population, thereby reducing methanogens symbiotically associated with the protozoal population. Machmuller et al (2003) confirm through their study that methanogenesis in the rumen may not always be correlated with the number of methanogens wich support our results, in addition, Guo et al (2008) have suggested that methane production may also be affected by reducing rate of methanogenesis via decreasing the activity of methane producing gene without changing the total methanogen population.Regarding the effect of the differents fractions against $\mathrm{CH}_{4}$ production and related ruminal microbes, several investigations have been done worldwide, for instance, Bodas et al (2008) suggest that reduced methane emission by flavonoids rich extract after $24 \mathrm{~h}$ incubation may be due to the change in ciliate protozoa community, however, Patra and Saxena(2010) reported that flavonoids gave direct effect against methanogens, and reduced protozoa related with ruminal methanogenesis. The simple Phenolic acids, as one of the main representatives of TP fraction, such as pcoumaric acid, ferulic acid, cinnamic acid were significantly effectives on methane emission when added at 5Mm using in vitro gas production technique (Jayanegara et al., 2010). Similarly, in another study, the same phenolics acids were tested at $0.1 \%$ concentration (w/v) in vitro (Ushida et al., 1989), the decrease in the methane emission was attributed by the authors to the inactivation of ciliate protozoa by these phenolic monomers. In addition, Kamra et al (2006) reported that methanogenesis was completely inhibited in the presence of $5 \mathrm{Mm}$ of bromoethanesulphonic acid (BES), however the numbers of methanogens, estimated by real time PCR, were not completely eliminated. A number of studies reported that tannin extracts or tannin-containing plants reduced the methanogenesis both in vitro (Patra et al., 2006; Bhatta et al., 2009) and in vivo (Animut et al., 2008; Grainger et al., 2009) via a direct inhibitory effect on methanogens population (field et al., 1989; Tavendale et al., 2005) or without any effect on methanogens growth (Patra and saxena, 2010). Mosoni et al.2011 reported that although défaunation reduced $\mathrm{CH}_{4}$ emission, ruminal methanogen density increased 10 -fold.

Table 04: Effect of the two plants extracts on methanogenic forming Archaea and ciliate protozoa after 24h in vitro incubation (Means \pm SD).

\begin{tabular}{|c|c|c|c|c|c|}
\hline & Control Diet & CNE & CSE & P-value & S.E.M \\
\hline $\begin{array}{c}\text { Methanogenic Archaea } \\
\left(\times 10^{5}\right)\end{array}$ & $8.47^{\mathrm{a}} \pm 1.17$ & $6.74^{\mathrm{a}} \pm 5.56$ & $5.88^{\mathrm{a}} \pm 5.47$ & 0.615 & 1.041 \\
\hline $\begin{array}{c}\text { Ciliate protozoa } \\
\left(\times 10^{3}\right)\end{array}$ & $3.85^{\mathrm{c}} \pm 0.57$ & $2.98^{\mathrm{b}} \pm 0.65$ & $2.09^{\mathrm{a}} \pm 0.45$ & $<0.0001$ & 0.246 \\
\hline
\end{tabular}

CNE: C.nobile extract; CSE: C. segetum extract; S.E.M: Standard error of the mean; P: Probability; ${ }^{\text {a b, }}$, means with different superscripts within a same line are significantly different $(\mathrm{P}<0.05)$.

Table 05: Correlation coefficients between phytochemicals, methane production $(\mathrm{ml})$ and related forming microbes.

\begin{tabular}{|c|c|c|c|}
\hline Parameters & $\mathrm{CH}_{4}(\mathrm{ml})$ & Methanogens $\left(\times 10^{5}\right)$ & Ciliate-protozoa $\left(\times 10^{3}\right)$ \\
\hline TP & $-0.861^{* *}$ & $-0.270^{\mathrm{ns}}$ & $-0.820^{* *}$ \\
\hline TF & $-0.916^{* *}$ & $-0.168^{\text {ns }}$ & $-0.691^{* *}$ \\
\hline CT & $-0.538^{*}$ & $-0.002^{\text {ns }}$ & $-0.562^{*}$ \\
\hline
\end{tabular}

TP: Total Phenol, TF: Total Flavonoids, CT: Condensed tanins; n.s: not significant; *: $p<0.05 ;{ }^{* *} \mathrm{p}<0.01$.

The amount of microbial biomass (MBM) is an important indicator to the progress of rumen fermentation, the growth of the major rumen microbes was more vigorous, and it was obvious that their numbers and metabolism were significantly extended in added C. nobile extract samples (increasing by $11 \%$ comparatively to the control), while this of $C$. segetum extract treatment and that of control were statistically similar. It is probably that the inhibitory effect on ciliate protozoa population allowed gram-negative, propionate-producer species, such as Selenomonas ruminantium, to grow up and increasing the accumulation of propionate (table 03), thereby increasing the total microbial biomass. Our results are consistent with those of Broudiscou et al (2002) reporting that some 
plant extracts with high flavonoids content decreased methane production and increased both degradability of crude protein and cell wall constituents resulting in increased biomass production.

\section{Conclusion}

The present study introduces a new plant extracts which have shown a potent antimethanogenic potential without affecting the major nutritional parameters. Despite that, screening of wide range of other available plants extracts would be much more efficient when common properties such as different phenolic fractions could be identified by using advanced chemistry tools, in order to obtain a better understanding of the role of each active component on $\mathrm{CH}_{4}$ mitigation. In addition, previous long-term in vitro studies with some plant extracts demonstrated that the effects of some plant extracts on rumen microbial fermentation disappeared after several days of incubation, suggesting that ruminal microorganisms may adapt to the presence of these compounds. Considering the above results, future research in long-term studies (in vitro and in vivo) may help to establish the efficacy of these plant extracts as rumen microbial modulators by determining the dosages required and their mechanism of action against rumen microbes population.

\section{Aknowledgment}

The authors thank very sincerely all those contributed in the achievement of this research from C.R.Bt and from DMVPA for their technical assistance.

\section{References}

1. Ammar, H., López, S. and Gonzalez, J.S. (2005). Assessment of the digestibility of some Mediterranean shrubs by in vitro techniques. Anim Feed Sci Technol., 119: 323-331.

2. Animut, G., Goetsch, A.L., Puchala, R., Patra, A.K., Sahlu, T., Varel, V.H. and Wells, J. (2008). Methane emission by goats consuming diets with different levels of condensed tannins from lespedeza. Anim. Feed Sci. Technol., 144, 212-227.

3. AOAC (1990): Official Methods of Analysis.15th ed. Association of Official Analytical Chemists, Arlington, VA.

4. Arhab, R., Macheboeuf, D., Aggoun, M., Bousseboua, H., Viala, D. and Besle, J.M. (2009). effect of polyethylene glycol on in vitro gas production and digestibility of tannin containing feedstuffs from north african arid zone. Trop.Subtrop. Agroecosys., 10(3) : 475-486.

5. Avula, B., Wanga, Y.H., Wanga,M., Avontoa, C., Zhaoa,J., Smilliea, T.J., Ruac,D. and Khan,I.A.(2014). Quantitative determination of phenolic compounds by UHPLC-UV-MS and use of partial least-square discriminant analysis to differentiate chemo-types of Chamomile/Chrysanthemum flower heads. J. Pharm. Biomed. Anal.., $88: 278-288$.

6. Ayeb, N., Seddik, M., Hammadi, M., Barmat, A., Atigui, M., Harrabi, H. and Khorchani, T. (2013).Effects of feed resources in arid lands on growth performance of local goat kids in southern Tunisia. Opt. méditerranéennes.107:97-102

7. Balcells, J ., Aris, A., Serrano, A ., Seradj, A.R., Crespo, J. and Devant, M. (2012).Effects of an extract of plant flavonoids (Bioflavex) on rumen fermentation and performance in heifers fed highconcentrate diets. Anim. Feed. Sci. Technol., 90 :4975-4984.

8. Beauchemin, K.A., McGinn, S.M., Martinez, T.F. and McAllister, T.A. (2007). Use of condensed tannin extract from quebracho trees to reduce methane emissions.Anim. Feed. Sci. Technol., $85: 1990-1996$.

9. Belanche, A., de la Fuente, G. and Newbold C.G. (2014).Study of methanogen communities associated with different rumen protozoal populations.FEMS Microbiol Ecol., 90 : 663-677.

10. Bhatta, R., Uyeno, Y., Tajima, K., Takenaka, A., Yabumoto, Y., Nonaka, I., Enishi, O. and Kurihara, M. (2009). Difference in the nature of tannins on in vitro ruminal methane and volatile fatty acid production and on methanogenic archaea and protozoal populations. J. Dairy Sci., 92: 5512-5522.

11. Bodas, R., López, S., Fernández, M., Garcia-Gonzáles, R., Wallace R.J. and Gonzáles J.S. (2009). Phytogenic additives to decrease in vitro ruminal methanogenesis. Opt. Méditerranéennes., 85:279-283.

12. Bodas, R., López, S., Fernandez, M., Garcia-Gonzalez, R., Rodriguez, A.B., Wallace, R.J. and Gonzalez, J.S. (2008). In vitro screening of the potential of numerous plant species as antimethanogenic feed additives for ruminants. Anim. Feed Sci. Technol., $145: 245-258$.

13. Blûmel, M., Makkar, H.P.S. and Beker, K. (1997). In vitro gas production: a technique revisited.J. Anim. Physiol. And Anim. Nutr., 77: 24-34. 
14. Boufennara, S., López, S., Bousseboua, H., Bodas, R. and Bouazza, L.(2012).Chemical composition and digestibility of some browse plant species collected from Algerian arid rangelands. Span. J. Agric. Res., 10(1): 88-98.

15. Broudiscou, L.P., Papon, Y. and Broudiscou, A.F. (2000). Effect of dry plant extracts on fermentation and methanogenesis in continuous culture of rumen microbes, Anim. Feed Sci. Technol., 87 : 263- 277.

16. Broudiscou, L. P., Papon, Y. and Broudiscou, A.F.( 2002). Effects of dry plant extract on feed degradation and proportion of rumen microbial biomass in a dual flow ferments. Anim. Feed Sci. Technol., 101 : $183-189$.

17. Cabiddu, A., Decandia, M., Sitzia, M. and Molle, G. (2000). A note on the chemical composition and tannin content of some Mediterranean shrubs browsed by Sarda goats. Opt. Méditerranéennes.,52: 175-178.

18. Carberry, C.A., Kenny, D.A., Kelly, A.K. and Waters, S.M. (2014). Quantitative analysis of ruminal methanogenic microbial populations in beef cattle divergent in phenotypic residual feed intake (RFI) offered contrasting diets.Anim. Feed Sci. Technol., 5:41.

19. Carnat, A., Carnat, A.P., Fraisse, D., Ricoux, L. and J.L. Lamaison. (2004).The aromatic and polyphenolic composition of Roman camomile tea. J.Fitote., 75 :32-38.

20. Cushnie, T. P. T. and Lamb, A. J. (2011)Recent advances in understanding the antibacterial properties of flavonoids,Int J Antimicrob Agents., 38 (2) : 99-107.

21. Demeyer, D.I. and van Nevel, C.J. (1975) Methanogenesis, an integrated part of carbohydrate fermentation and its control, in: McDonaldn I.W., Warnern A.C.I. (Eds.), Digestion and Metabolism in the Ruminant, University of New England Publishing Unit, Armidale, pp. 366-382.

22. Demeyer, D.I.,Fiedler, D. and De Graeve, K.G.(1996).Attempted induction of reductive acetogenesis into the rumen fermentation in vitro.Reprod. Nutr. Dev.,36 :233-240.

23. Field, J.A., Kortekaas, S. and Lettinga, G. (1989). The tannin theory of methanogenic toxicity. Biol. Wastes., $29,241-262$.

24. Denman, S. E., Tomkins, N. W. and McSweeney C. S. (2007).Quantitation and diversity analysis of ruminal methanogenic populations in response to the antimethanogenic compound bromochloromethane. FEMS Microbiol Ecol., 62: 313-322.

25. Denman, S. E. and McSweeney, C. S. (2005). Quantitative (Real Time) PCR. In: H. Makkar, C. S., McSweeney, Methods in Gut Microbial Ecology for Ruminants. Springer, New York, USA: 105-115.

26. Fraisse,D.; Felgines, C., Texier, O. and Lamaison, J.L.(2011). Caffeoyl Derivatives: Major Antioxidant Compounds of Some Wild Herbs of the Asteraceae Family. Food and Nutr Sci.2 :181-192.

27. Garcia-Gonzalez, R., López, S., Fernandez, M., Bodas, R. and Gonzalez, J.S.(2008a). Screening the activity of plants and spices for decreasing ruminal methane production in vitro. Anim. Feed Sci. Technol., 147 : 36-52.

28. García-González, R., López, S., Fernandez, M., Gonzalez, J.S.(2008b). Dose-response effects of Rheum officinale root and Frangula alnus bark on ruminal methane production in vitro. Anim. Feed Sci. Technol., 145 : 319-334.

29. Geissman, T. A. and Steelink C. (1957), Flavonoid petal constituents of Chrysanthemum segetum L. J. Ore. Chem., 22 : 946-948.

30. Guimaràtes,R., Barros,L., Dueñas, M., Calhelha, R.C., Carvalho , A.M., Buelga, C.S., Queiroz, M.J.R.P.,. Ferreira, I.C.F.R. (2013).Nutrients, phytochemicals and bioactivity of wild Roman chamomile: A comparison between the herb and its preparations.Food Chem., 136: 718-725.

31. Grainger, C., Clarke, T., Auldist, M.J., Beauchemin, K.A., McGinn, S.M., Waghorn, G.C. and Eckard, R.J. (2009). Potential use of Acacia mearnsii condensed tannins to reduce methane emissions and nitrogen excretion from grazing dairy cows. Can. J. Anim. Sci., 89: 241-251.

32. Guo, Y.Q., Liu, J.-X., Lu, Y., Zhu, W.Y., Denman, S.E. and McSweeney, C.S. (2008). Effect of tea saponin on methanogenesis, microbial community structure and expression of mcrA gene, in cultures of rumen microorganisms. Lett. Appl. Microbiol., $47: 421-426$.

33. Harborne, J.B., Heywood, V.H. and Saleh, N.A.M.(1970). Chemosystematics of the compositae: flavonoid patterns in the Chrysanthemum complex.Phytochem., 9 : 2011- 2017.

34. Hariadi, B.T. and Santoso, B. (2010). Evaluation of tropical plants containing tannin on in vitro methanogenesis and fermentation parameters using rumen fluid. J Sci Food Agric., 90:456-461.

35. Heimler, D ., Vignolini, P ., Giulia Dini, M ., Francesco Vincieri F . andRmani (2006).Antiradical activity and polyphenol composition of localBrassicaceae edible varieties. Food Chem., 99:464-469.

36. Hiai, S., Oura, H. and Nakajima, T. (1976). Color reaction of some sapogenins and saponins with vanillin and sulfuric acid. Planta Med., 29: 116-122 
37. Hook, S.E., Steele, M.A., Northwood, K.S, Wright, A.D.G. and McBride, B.W. 2011. Impact of highconcentrate feeding and low ruminal $\mathrm{pH}$ on methanogens and protozoa in the rumen of dairy cows. Microb. Ecol., 62:94 -105.

38. Jayanegara, A., Wina, E., Soliva, C.R., Marquardt, S., Kreuzer, M. and Leiber F. (2011). Dependence of forage quality and methanogenic potential of tropical plants on their phenolic fractions as determined by principal component analysis. Anim Feed Sci Technol., 163:231-2430.

39. Jayanegara, A., Goel, G., Makkar, H.P.S. and Becker, k. (2010). Reduction in Methane Emissions from Ruminants by Plant Secondary Metabolites: Effects of Polyphenols and Saponins. FAO Proc..indb., 153 : 151 157.

40. Kamra, D.N., Agarwal, N. and Chaudhary, L.C. (2006). Inhibition of ruminal methanogenesis by tropical plants containing secondary compounds. Int. Cong. Series., $1293: 156-163$.

41. Kenny, O., Smyth, T. J., Walsh, D., Kelleher, C. T., Hewage, C. M. and Brunton N. P. (2014). Investigating the potential of under-utilised plants from the Asteraceae family as a source of natural antimicrobial and antioxidant extracts. Food Chem., 161: 79-86.

42. Kim, E. T., Guan, L. L., Lee, S. J., Lee, S .M., Lee, S. S., Lee, I. D., Lee, S. K. and Lee S. S. (2015). Effects of Flavonoid-rich Plant Extracts on In vitro Ruminal Methanogenesis, Microbial Populations and Fermentation Characteristics. Asian-Australas J Anim Sci. 28(4): 530-537.

43. Kim, E.T., Kim., C.H., Min, K.S. and Lee, S.S. (2012).Effects of Plant Extracts on Microbial Population, Methane Emission and Ruminal Fermentation Characteristics.Asian-Australas J Anim Sci. 25(6):806-11.

44. Kulivand,M. and Kafilzadeh, F.(2015).Correlation between chemical composition, kinetics of fermentation and methane production of eight pasture grasses. ActaSciAnimSci. 37(1) : 9-14.

45. Kumar, S., Puniya, A.K., Puniya, M., Dagar,S.S., Sirohi,S.K., Singh, K. and Griffith, G.Y.(2009).Factors affecting rumen methanogens and methane mitigation strategies.WorldJMicrobiol and Biotech., 25(9) : 15571566.

46. Lascano, C.E. and Cárdenas, E. (2010). Alternatives for methane emission mitigation in livestocksystems.R. Bras. Zootec., 39 : 175-182.

47. López, S., Makkar, H.P.S. and Soliva, C.R. (2010). Screening plants and plant products for methane inhibitors. In: Vercoe, P.E. ., Makkar,H.P.S. and Schlink,A.C. (Editors). In Vitro Screening of Plant Resources for ExtraNutritional Attributes in Ruminants: Nuclear and Related Methodologies. Springer, Dordrecht.

48. Machmuller,A., Soliva, C.R. and Kreuzer, M. (2003).Effect of coconut oil and defaunation treatment on methanogenesis in sheep. Reprod. Nutr. Dev., 43: 41-55.

49. Maeda, H., Fujimoto, C., Haruki, Y., Maeda, T., Kokeguchi, S., Petelin, M., Arai, H., Tanimoto, I., Nishimura, F. and Takashiba, S.(2003). Quantitative real-time PCR using TaqMan and SYBR Green for Actinobacillus actinomycetemcomitans, Porphyromonas gingivalis, Prevotella intermedia, tetQ gene and total bacteria. FEMS Immunol. Med. Microbiol., 39: 81-86.

50. Makkar, H.P.S., Blümmel, M. and Becker, K. (1995a). In vitro effects of and interactions between tannins and saponins and the fate of tannins in the rumen. J. Sci. Food Agric., $69: 481-493$.

51. Makkar, H.P.S. (2003b). Effects and fate of tannins in ruminant animals, adaptation to tannins, and strategies to overcome detrimental effects of feeding tannin-rich feeds. Small Rum. Res., 49 : 241-256.

52. McSweeney, C.S., Palmer, B., McNeill, D.M. and Krause, D.O. (2001). Microbial interactions with tannins: nutritional consequences for ruminants. Anim. Feed Sci. Technol., 91 : 83-93.

53. Menke, K. H. and Steingass, H. (1988). Estimation of the energetic feed value obtained from chemical analysis and in vitro gas production using rumen fluid, Anim. Res.Dev., 28:7-55.

54. Miller, T.L. (1995). Ecology of methane production and hydrogen sinks in the rumen. In: Engelhardt, W., Leonhard-Marek, S., Breves, G., Giesecke, D. (Eds.), Ruminant Physiology. Stuttgart, Germany,pp :317-331.

55. Mitsumori., M. and Sun, W. (2008). Control of rumen microbial fermentation for mitigrating methane emissions from the rumen. Asian-Aust J Anim Sci.,21:144-154.

56. Mosoni, P., Martin, C., Forano, E. and Morgavi, D.P. (2011). Long term defaunation increases the abundance of cellulolytic ruminococci and methanogens but does not affect the bacterial and methanogen diversity in the rumen of sheep. J. Anim Sci., 89:783-791.

57. Moujahed, N., Darej, C., Taghouti ,M., Bouaziz, Y., BenMustapha, C. and Kayouli, C. (2013).Chemical composition and in vitro fermentation characteristics of range species growing in Central Tunisia.Opt. Méditerranéennes.121 -125

58. Nellot, L., Demeyer, D. and Verstracete, W. (1997). Effect of 2-bromoethanesulfonic acid and Peptostreptococcus productus ATCC 35244 addition on stimulation of reductive acetogenesis in the ruminal ecosystem by selective by inhibition of methanogens. Appl Environ Microbiol. 63:194-200. 
59. NRC 2001. Nutrient Requirements of Dairy Cattle. 7th Rev. edn.National Research Council, The National Academies Press, Washington, DC.

60. Ochocka, R., Danuta Rajzer, J., Kowalski, P.and Lamparczyk, H.(1995).Determination of coumarins from Chrysanthemum segetum by capillary electrophoresis. J Chromatogr A., 709 : 197-202.

61. Öksüz, S. and Wagner, H. (1982). Coumarins From Chrysanthemum segetum. J. Nat. Prod., 45 (3) : $374-374$.

62. Oliveira, S.G., Berchielli, T.T., Pedreira, M.S., Primavesi, O., Frighetto, R. and Lima, M.A. (2007). Effect of tannin levels in sorghum silage and concentrate supplementation on apparent digestibility and methane emission in beef cattle. Anim. Feed Sci. Technol., 135 : 236-248.

63. Orthofer, V.L. and Lamuela-Raventos R. (1999). Analysis of total phenols and other oxidation substrates and antioxidants by means of Folin-Ciocalteau reagent. Method. Enzymol., 299:152-178.

64. Oskoueian, E., Abdullah, N., Oskoueian, A., 2013. Effects of Flavonoids on Rumen Fermentation Activity, Methane Production, and Microbial Population. BioMed Res. Int., 386, 8.

65. Patra, A.K., Kamra, D.N. and Agarwal, N. (2006). Effect of plant extracts on in vitro methanogenesis, enzyme activities and fermentation of feed in rumen liquor of buffalo. Anim. Feed Sci. Technol., 128: $276-291$.

66. Patra, K. A. and Saxena J. (2010). A new perspective on the use of plant secondary metabolites to inhibit methanogenesis in the rumen. Phytochem., 71 (11-12): 1198-1222.

67. Puchala, R., Min, B.R., Goetsch, A.L. and Sahlu, T. (2005). The effect of a condensed tannin containing forage on methane emission by goats. Anim. Feed Sci. Technol., 83: 182-186.

68. Rochfort, S., Parker, A.J. and Dunshea, F.R. (2008). Plant bioactives for ruminal health and productivity. Phytochem., 69 : 299-322.

69. Santoso, B., Saragih, E.W. and Tj. Hariadi, B. (2013).effect of water extract of plants containing tannin on in vitro methagonesis and fermentation characteristics of the grass Pennisetum purpureophoides. J. IndonesianTrop.Anim.Agric., 38(1).

70. Seradj, A. R., Abecia, L., Crespo J., Villalba, D., Fondevila, M.and Balcells, J.(2014). The effect of Bioflavex® and its pure flavonoid components on in vitro fermentation parameters and methane production in rumen fluid from steers given high concentrate diets. Anim. Feed Sci. Technol., 197: 85-91.

71. Singleton, V.L., Orthofer, R. and Lamuela-Raventos, R.M. (1999). Analysis of total phenols and other oxidation substrates and antioxidants by means of Folin-Ciocalteu reagent. Methods Enzymol.,299 :152-178.

72. Skillman, L.C.1., Toovey, A.F., Williams, A.J. and Wright, A.D.(2006).Development and validation of a realtime PCR method to quantify rumen protozoa and examination of variability between entodinium populations in sheep offered a hay-based diet.Appl Environ Microbiol., 72(1):200-6.

73. Srivastava, J.K. and Gupta, S. (2009). Extraction, Characterization, Stability and Biological Activity of Flavonoids Isolated from Chamomile Flowers .Mol Cell Pharmacol., 1(3): 138.

74. Stewart, C.S. and Bryant, M.P. (1988) The rumen bacteria. In: Hobson PN (ed) The rumen microbial ecosystem. Elsevier Applied Science, New York, pp : 21-75

75. Stich, K., Halbwirth, H., Wurst, F. and Forkmannb, G. (1996).UDP-GIucose: Flavonol 7-O-glucosyItransferase Activity in Flower Extracts of Chrysanthemum segetum. Z. Naturforsch. C.52(3-4):153-8.

76. Stumm, C.K., Gijzen, H.J. and Vogels, G.D. (1982). Association of methanogenic bacteria with ovine rumen ciliates. Br J Nutr., 47: 95-99.

77. Tavendale, M.H., Meagher, L.P., Pacheco, D., Walker, N., Attwood, G.T. and Sivakumaran, S. (2005). Methane production from in vitro rumen incubations with Lotus pedunculatus and Medicago sativa, and effects of extractable condensed tannin fractions on methanogenesis. Anim. Feed Sci. Technol., 123-124 : 403-419.

78. Theodorou, M.K., Williams, B.A., Dhanoa, M.S., Mcallan, A.B. and France, j. (1994). A simple gas production method using a pressure transducer to determine the fermentation kinetics of ruminant feeds. Anim. Feed Sci. Technol., 48:185-197.

79. Tiemann, T.T., Lascano, C.E., Kreuzer, M. and Hess, H.D. (2008). The ruminal degradability of fibre explains part of the low nutritional value and reduced methanogenesis in highly tanniniferous tropical legumes. J. Sci. Food Agric., 88 : 1794-1803.

80. Tschan, G.M., Konig,G.M.,. Wright, A.D. and Stichert, O.(1996).Chamaemeloside, a new flavonoid glycoside from Chamaemelum nobile.Phytochem.41(2) : 643-646.

81. Tubiello, F.N., Salvatore, M., CóndorGolec, R.D., Ferrara, A., Rossi,S., Biancalani, R.

82. Federici, H., Jacobs, A. and Flammini. (2014). Agriculture, Forestry and Other Land Use Emissions by Sources and Removals by Sinks, 1990-2011 Analysis. Food and agriculture organization (FAO) of the united nations.ESS/14-02.

83. Türkoğlu, A., Duru, ME., Mercan, N., Kivrak, I. and Gezer, K. (2007): Antioxidant and antimicrobial activities of Laetiporus sulphureus (Bull.) Murill. Food Chem., 101: 267-273. 
84. Ushida,K., Tanaka, H. and Kjima,Y. (1989). Effect of phenolic acids on gas and volatile fatty acid production by mixed rumen population with or without protozoa, Jpn. J. Zootech. Sci., 60 : 1135-1142.

85. Van Nevel C.J. and Demeyer, D.I (1996). Control of rumen methanogenesis. Environ Mon Assess., 42:73-97.

86. Valant-Vetschera,K.M., Wollenweber ,E ., Faure, R and Gaydou,E. (2003). New exudate flavonoids of species from the Chrysanthemum complex (Asteraceae- Anthemideae). .BiochemSyst Ecol., 31: 545-548.

87. Williams, C.A., Greenham, J. and Harborne, J.B.(2001).The role of lipophilic and polar flavonoids in the classification of temperate members of the Anthemideae. BiochemSyst Ecol., 29(9):929-945. 